\title{
Influence of Particle Size on the Effectiveness of the Fiber in Alfalfa Silage
}

\author{
P. W. Clark* and L. E. Armentano† \\ *Department of Animal and Food Science, \\ University of Wisconsin-River Falls, River Falls 54022-5001 \\ †Department of Dairy Science, \\ University of Wisconsin, Madison 53706-1284
}

\begin{abstract}
The objective was to determine the influence of alfalfa silage particle length on milk yield, milk composition, and chewing activity. Sixteen multiparous lactating Holsteins were used in each of two separate feeding trials over a 2-yr period providing two repetitions. Each trial was based on $4 \times 4$ Latin squares with 21 -d periods. All four diets (2-yr average, dry basis) contained a basal level of $10.7 \%$ neutral detergent fiber from corn silage and $2.3 \%$ neutral detergent fiber from chopped alfalfagrass hay. One of the diets served as a low forage, low fiber control and contained only the basal forages. The other three diets contained an additional 8.6\% neutral detergent fiber from coarser alfalfa silage, finely rechopped alfalfa silage or an equal mixture of the two. An increase in the forage content above the basal amount using alfalfa silage increased $4 \%$ fat-corrected milk yield, milk fat yield and concentration, eating time, and total chewing time. Dry matter intake was not influenced by diet. Linear increases in rumination and total chewing times were observed as the mean particle size of the alfalfa silage increased from finer to coarser. There was no linear effect of alfalfa silage particle size on milk yield, $4 \%$ fat-corrected milk yield, dry matter intake, or milk composition.
\end{abstract}

(Key words: alfalfa silage, fiber, particle size)

Abbreviation key: ALF = alfalfa silage, $\mathbf{B L F}=$ basal, low forage control diet, HFCAS = high forage, coarser alfalfa silage diet, HFFAS = high forage, finer alfalfa silage diet, HFMAS = high forage, medium alfalfa silage diet.

\section{INTRODUCTION}

The foundation of a high-producing dairy cow's diet is high quality, low fiber forage. Forages provide energy

Received August 15, 2001

Accepted June 26, 2002.

Corresponding author: Perry Wilson Clark; e-mail: perry.w. clark@uwrf.edu. as well as fiber to maintain ruminal function and normal milk fat concentration. Physically effective fiber is the fraction of the diet that stimulates chewing and is related to the physical characteristics of NDF (primarily particle size) that affect chewing activity (NRC, 2001). To ensure adequate fiber, the NRC (2001) recommends the concentration of total dietary NDF for lactating cows fed diets with alfalfa or corn silage as the predominate forage and dry corn grain be at least $25 \%$ of dietary DM. The recommendation also states that $19 \%$ of dietary DM should be NDF from forage. The minimum amount of total diet NDF can be adjusted upward as the amount of NDF from forage is reduced or as forage particle size is reduced.

Dairy herd managers often strive to maximize the use of ensiled forage crops because they are more easily accommodated by TMR feeding systems and are often of higher quality compared to dry hay. Ensiled hay crops must be reduced to a mean particle length sufficient to ensure good packing without compromising the physical effectiveness of the fiber in the forage.

Adequate silage particle length is critical for proper rumen function. As mean silage particle size decreases, chewing time and rumen $\mathrm{pH}$ decline due to a reduction in saliva production and its buffering action (Woodford and Murphy, 1988; Grant and Colenbrander, 1990a). Low ruminal $\mathrm{pH}$ is associated with suppression of milk fat synthesis, possibly due to the formation of transC18:1 fatty acids in the rumen as a result of incomplete biohydrogenation of unsaturated dietary fatty acids (Kalscheur et al., 1997). Insufficient forage particle length also decreases the molar ratio of acetate to propionate in rumen fluid, which is associated with milk fat depression (Santini et al., 1983; Shaver et al., 1988; Grant and Colenbrander, 1990a).

A reduction in forage particle size has increased DMI, decreased DM digestibility, and decreased retention time of solids in the rumen (Jaster and Murphy, 1983; Martz and Belyea, 1986). Smaller forage particles leave the rumen faster, which may account for both the increased DMI and the reduced digestibility. In a summary of the relationships between physically effective 
dietary fiber and rumen fermentation, Allen (1997) reported that forages appear to have a critical mean particle size, above which additional length adds little benefit. Beauchemin et al. (1994) demonstrated that alfalfa silage (ALF) chop length was less critical when total diet forage level was consistent with NRC (1989) recommendations. Studies have generally altered the particle size of the entire forage supply. Frequently, several forages are fed in mixed dairy diets; the potential of using forages of different length in a complementary manner is of practical importance and may allow both animal performance and the ensiling process to be optimized. The objective of this study was to determine the effect of ALF particle size on milk yield, milk composition, and chewing behavior. The effects of increased alfalfa particle size were determined in the presence of a basal amount of long forage fiber. The effect of adding alfalfa in place of concentrate, irrespective of particle size, was also determined.

\section{MATERIALS AND METHODS}

\section{Yr 1}

Experimental cows and diets. Sixteen multiparous Holstein cows in mid-lactation were used in four replications of a $4 \times 4$ Latin square design with 21 -d periods. This design was conducted in the fall of 1996 and repeated in the fall of 1997, using 16 cows each year. One cow was dropped from the study due to a teat injury. Cows were blocked into four groups by stage of lactation. Cows in blocks 1 to 4 ranged from 71 to 73,77 to 80, 82 to 94 , and 97 to 118 DIM, respectively, at the start of the trial. Housing consisted of a conventional tie stall barn. Cows were fed a TMR prepared once daily and offered in two separate feedings at 1700 and 600 $\mathrm{h}$ following milking.

The first cutting alfalfa and corn silage were harvested at a theoretical chop length of $9.4 \mathrm{~mm}$ and stored in $4.3 \times 15.2 \mathrm{~m}$ upright concrete stave silos. The composition of each feed was determined (Table 1). The finer ALF had the same chemical composition as the coarser ALF because the finer silage was prepared each day by rechopping the coarser silage using a Gehl forage recutter (Gehl, Inc., West Bend, WI) with a $33 \mathrm{~mm}$ round-hole screen prior to feeding. The composition of the diets is shown in Table 2. One main difference among diets was that the basal, low forage, low fiber control diet (BLF) had a much higher (73.4\%) concentrate level compared to the ALF diets (52.8\%). The primary difference among the ALF diets was the particle length of the ALF. The BLF contained $10.5 \mathrm{~g}$ NDF from corn silage and $2.5 \mathrm{~g}$ NDF from chopped grass hay per $100 \mathrm{~g}$ DM (Table 3). The ALF diets contained the same amounts of corn silage and chopped hay as BLF, plus an additional 8\% NDF from either coarser ALF (HFCAS), finer ALF (HFFAS), or medium ALF (HFMAS), created from an equal mixture of coarser and finer ALF. This design allowed the addition of ALF fiber to be compared with the BLF, and allowed the comparison of ALF with differing mean particle sizes.

The high moisture shelled corn was coarsely rolled before it was fed. All cows were fed the same pretrial adjustment diet for $10 \mathrm{~d}$ prior to the start of the first 21-d period. The pre-trial diet contained 10.5, 2.5, and $4.5 \mathrm{~g}$ per $100 \mathrm{~g}$ DM from corn silage, chopped hay, and ALF, respectively. All diets were fed for ad libitum intake and a refusal rate of 5 to 8\% (as-fed). Cows were immediately switched to a new diet at the beginning of each period. The DMI data were collected on $d 17$ to 21 of each period. Orts were weighed and sampled for DM determination.

Feed and milk sampling and analysis. All feeds were sampled weekly and composited at the end of each period. The DM determination was determined by oven drying at $60^{\circ} \mathrm{C}$ for $48 \mathrm{~h}$. Feed samples were ground in a Wiley mill (2-mm screen; Arthur H. Thomas, Philadelphia, PA). Feed fiber analysis was performed according to the method of Van Soest et al. (1991) with the following modifications recommended by D. R. Mertens (1992, personal communication); for all samples, sodium sulfite ( $0.5 \mathrm{~g}$ per sample) was added, and 1205 units of $\alpha$ amylase (A-3306; Sigma Chemical Co., St. Louis, MO) were added at boiling and again prior to filtration. Four acetone washes were used for fat extraction prior to the NDF procedure for the roasted soybean samples. Forage particle size analysis was done by Dairyland Laboratories (Arcadia, WI) according to the method described by the ASAE (1998). Samples were processed on an asfed basis using a sample size of approximately $3.8 \mathrm{l}$ and shaken for $2 \mathrm{~min}$.

The CP was determined by Kjeldahl analysis (AOAC, 1980). The RUP concentrations were estimated according to the NRC (1989). Fat percentages of feeds were determined by extraction and methylation of fatty acids followed by quantitation of those fatty acids with 14 to 18 carbons by GLC (Sukhija and Palmquist, 1988). The particle size of all forages was determined according to ASAE (1995) standard S424 (Table 4). The chemical composition of the diets was calculated from individual feedstuff analysis. Milk weights were recorded daily. Morning and evening milk samples were collected on d 16 to 20 of each period and analyzed for fat and protein by a commercial DHI laboratory (Ag Source Cooperative Services, Menomonie, WI). Daily milk component percentages were calculated on a weighted mean basis. Chewing activity was monitored for one continuous 24-h period on d 19 of each period. Cows were visually observed at 5 -min intervals. The 
Table 1. Chemical analysis of feeds.

\begin{tabular}{|c|c|c|c|c|c|c|c|}
\hline \multirow[b]{2}{*}{ Feed } & \multirow[b]{2}{*}{$\mathrm{yr}$} & \multicolumn{6}{|c|}{ Dietary Component } \\
\hline & & $\mathrm{DM}$ & $\mathrm{CP}$ & $\mathrm{NDF}$ & $\mathrm{ADF}$ & Fat $^{1}$ & $\mathrm{NFC}^{2}$ \\
\hline & & & & $(\mathrm{g} / 100 \mathrm{~g}$ & & - & \\
\hline \multirow[t]{2}{*}{ Alfalfa silage } & 1 & 33 & 18.6 & 40.1 & 37.2 & 1.8 & 30.0 \\
\hline & 2 & 41 & 21.4 & 36.1 & 33.0 & 1.4 & 31.6 \\
\hline \multirow[t]{2}{*}{ Corn silage } & 1 & 36 & 8.2 & 45.0 & 23.6 & 2.2 & 39.5 \\
\hline & 2 & 38 & 7.8 & 41.4 & 23.4 & 1.6 & 44.0 \\
\hline \multirow[t]{2}{*}{ Chopped hay (mixed alfalfa-grass) } & 1 & 86 & 12.9 & 58.0 & 40.5 & 1.4 & 18.4 \\
\hline & 2 & 86 & 16.6 & 60.9 & 49.1 & 0.8 & 12.4 \\
\hline \multirow[t]{2}{*}{ High moisture shelled corn } & 1 & 79 & 9.2 & 13.4 & 3.6 & 4.9 & 79.4 \\
\hline & 2 & 78 & 8.6 & 14.2 & 3.3 & 3.7 & 71.9 \\
\hline \multirow[t]{2}{*}{ Soybean meal } & 1 & 87 & 47.9 & 12.6 & 9.7 & 3.2 & 29.0 \\
\hline & 2 & 89 & 48.2 & 18.8 & 12.2 & 2.9 & 22.8 \\
\hline \multirow[t]{2}{*}{ Roasted soybeans } & 1 & 96 & 39.0 & 17.7 & 9.7 & 22.7 & 15.5 \\
\hline & 2 & 97 & 42.5 & 16.2 & 10.1 & 15.6 & 20.6 \\
\hline
\end{tabular}

${ }^{1} \mathrm{Fat}=$ Sum of $\mathrm{C}_{14}$ to $\mathrm{C}_{18}$ fatty acids.

${ }^{2}$ Nonfiber carbohydrates; calculated as $100-[\mathrm{NDF}$ (percentage) + CP (percentage) + fat (percentage) + ash (percentage)]. Ash values were derived from NRC (1989).

action recorded at each observation was attributed to the entire 5-min interval. The data were pooled to achieve the group mean values in Table 5.

\section{Yr 2}

All aspects of the experimental design for yr 2 were the same as described for yr 1 . Four of the cows used in yr 1 were used again in yr 2. One cow was dropped from the study because she refused to eat the BLF diet at a level sufficient to sustain normal DMI and milk yield. Cows were blocked into four groups by stage of lactation. Cows in blocks one to four ranged from 38 to 55, 68 to 91,102 to 128 , and 139 to 150 DIM at the start of the trial. First, cutting alfalfa and corn silage were harvested at a theoretical chop length of $9.4 \mathrm{~mm}$

Table 2. Diet composition.

\begin{tabular}{|c|c|c|c|c|c|}
\hline \multirow[b]{2}{*}{ Feed } & \multirow[b]{2}{*}{$\mathrm{yr}$} & \multicolumn{4}{|c|}{$\operatorname{Diet}^{1}$} \\
\hline & & BLF & HFCAS & HFMAS & HFFAS \\
\hline & & & - $(\mathrm{g} /$ & $\mathrm{f} \mathrm{DM})$ & \\
\hline \multirow[t]{2}{*}{ Coarser alfalfa haylage } & 1 & 0 & 20.6 & 10.3 & 0 \\
\hline & 2 & 0 & 24.3 & 12.2 & 0 \\
\hline \multirow[t]{2}{*}{ Finer alfalfa haylage } & 1 & 0 & 0 & 10.3 & 20.6 \\
\hline & 2 & 0 & 0 & 12.2 & 24.3 \\
\hline \multirow{2}{*}{ Corn silage } & 1 & 21.6 & 21.6 & 21.6 & 21.6 \\
\hline & 2 & 22.3 & 22.3 & 22.3 & 22.3 \\
\hline \multirow{2}{*}{ Chopped hay (mixed alfalfa-grass) } & 1 & 5.0 & 5.0 & 5.0 & 5.0 \\
\hline & 2 & 4.9 & 4.9 & 4.9 & 4.9 \\
\hline \multirow[t]{2}{*}{ High moisture shelled corn } & 1 & 43.3 & 27.2 & 27.2 & 27.2 \\
\hline & 2 & 44.7 & 27.0 & 27.0 & 27.0 \\
\hline \multirow[t]{2}{*}{ Soybean meal } & 1 & 18.1 & 14.2 & 14.2 & 14.2 \\
\hline & 2 & 16.3 & 9.8 & 9.8 & 9.8 \\
\hline \multirow[t]{2}{*}{ Roasted soybeans } & 1 & 9.0 & 9.0 & 9.0 & 9.0 \\
\hline & 2 & 9.1 & 9.1 & 9.1 & 9.1 \\
\hline \multirow{2}{*}{ Mineral and vitamins } & $1^{2}$ & 2.4 & 2.4 & 2.4 & 2.4 \\
\hline & $2^{3}$ & 1.4 & 2.0 & 2.0 & 2.0 \\
\hline \multirow[t]{2}{*}{ Calcium carbonate } & 1 & 0.6 & 0 & 0 & 0 \\
\hline & 2 & 1.3 & 0.6 & 0.6 & 0.6 \\
\hline
\end{tabular}

${ }^{1} \mathrm{BLF}=$ Basal, low forage, control diet; HFCAS = high forage, coarser alfalfa silage diet; HFMAS = high forage, medium alfalfa silage diet; HFFAS = high forage, finer alfalfa silage diet.

${ }^{2}$ Contained (dry basis): $20 \% \mathrm{Ca}, 5.7 \% \mathrm{P}, 3.5 \% \mathrm{Mg}, 8 \% \mathrm{Na}, 12 \% \mathrm{C} 1,0.9 \% \mathrm{~K}, 1.3 \% \mathrm{~S}, 10 \mathrm{ppm} \mathrm{Co}, 429 \mathrm{ppm}$ $\mathrm{Cu}, 29 \mathrm{ppm}$ I, $1800 \mathrm{ppm} \mathrm{Mn,} 11 \mathrm{ppm}$ Se, $1700 \mathrm{ppm} \mathrm{Zn,} \mathrm{232,000} \mathrm{IU/kg} \mathrm{of} \mathrm{vitamin} \mathrm{A,} \mathrm{51,000} \mathrm{IU/kg} \mathrm{of} \mathrm{vitamin}$ $\mathrm{D}$, and $825 \mathrm{IU} / \mathrm{kg}$ of vitamin $\mathrm{E}$.

${ }^{3}$ Contained (dry basis): $20 \% \mathrm{Ca}, 6 \% \mathrm{P}, 4 \% \mathrm{Mg}, 8 \% \mathrm{Na}, 13 \% \mathrm{C} 1,1 \% \mathrm{~K}, 1 \% \mathrm{~S}, 10 \mathrm{ppm} \mathrm{Co}, 429 \mathrm{ppm} \mathrm{Cu}, 29$ ppm I, $1800 \mathrm{ppm} \mathrm{Mn,} 11 \mathrm{ppm}$ Se, $1700 \mathrm{ppm} \mathrm{Zn,} \mathrm{232,000} \mathrm{IU/kg} \mathrm{of} \mathrm{vitamin} \mathrm{A,} \mathrm{51,000} \mathrm{IU/kg} \mathrm{of} \mathrm{vitamin} \mathrm{D,}$ and $825 \mathrm{IU} / \mathrm{kg}$ of vitamin E. 
Table 3. Chemical composition of diets.

\begin{tabular}{|c|c|c|c|c|c|}
\hline \multirow{2}{*}{$\begin{array}{l}\text { Dietary } \\
\text { Component }\end{array}$} & \multirow[b]{2}{*}{$\mathrm{yr}$} & \multicolumn{4}{|c|}{$\operatorname{Diet}^{1}$} \\
\hline & & BLF & HFCAS & HFMAS & HFFAS \\
\hline \multirow{2}{*}{$\mathrm{DM}, \mathrm{g} / 100 \mathrm{~g}$ (as fed) } & 1 & 65.0 & 52.4 & 52.4 & 52.4 \\
\hline & 2 & 65.7 & 55.1 & 55.1 & 55.1 \\
\hline \multirow[t]{2}{*}{$\mathrm{NE}_{\mathrm{L}}^{2} \mathrm{Mcal} / \mathrm{kg}$ of $\mathrm{DM}$} & 1 & 1.83 & 1.69 & 1.69 & 1.69 \\
\hline & 2 & 1.83 & 1.67 & 1.67 & 1.67 \\
\hline \multirow[t]{2}{*}{$\mathrm{CP}$} & 1 & 18.6 & 19.0 & 19.0 & 19.0 \\
\hline & 2 & 18.1 & 18.7 & 18.7 & 18.7 \\
\hline \multirow[t]{2}{*}{ Fat $^{3}$} & 1 & 5.0 & 4.5 & 4.5 & 4.5 \\
\hline & 2 & 3.9 & 3.5 & 3.5 & 3.5 \\
\hline \multirow[t]{2}{*}{$\mathrm{ADF}$} & 1 & 11.3 & 18.0 & 18.0 & 18.0 \\
\hline & 2 & 12.0 & 18.7 & 18.7 & 18.7 \\
\hline \multirow[t]{2}{*}{ Total NDF } & 1 & 18.6 & 25.6 & 25.6 & 25.6 \\
\hline & 2 & 23.1 & 28.3 & 28.3 & 28.3 \\
\hline \multirow{2}{*}{ NDF from corn silage } & 1 & 10.5 & 10.5 & 10.5 & 10.5 \\
\hline & 2 & 10.5 & 10.5 & 10.5 & 10.5 \\
\hline \multirow[t]{2}{*}{ NDF from chopped hay } & 1 & 2.5 & 2.5 & 2.5 & 2.5 \\
\hline & 2 & 2.5 & 2.5 & 2.5 & 2.5 \\
\hline \multirow{2}{*}{ NDF from alfalfa silage } & 1 & 0 & 8.3 & 8.3 & 8.3 \\
\hline & 2 & 0 & 8.8 & 8.8 & 8.8 \\
\hline \multirow[t]{2}{*}{$\mathrm{NFC}^{4}$} & 1 & 50.8 & 43.0 & 43.0 & 43.0 \\
\hline & 2 & 48.2 & 41.8 & 41.8 & 41.8 \\
\hline \multirow{2}{*}{ RUP $^{5}$} & 1 & 7.1 & 6.3 & 6.3 & 6.3 \\
\hline & 2 & 7.0 & 6.4 & 6.4 & 6.4 \\
\hline
\end{tabular}

${ }^{1} \mathrm{BLF}=$ Basal, low forage, control diet; HFCAS = high forage, coarser alfalfa silage diet; HFMAS = high forage, medium alfalfa silage diet; and HFFAS = high forage, finer alfalfa silage diet.

${ }^{2} \mathrm{NE}_{\mathrm{L}}$ values were based on NRC (1989) values for individual feedstuffs.

${ }^{3}$ Sum of $\mathrm{C}_{14}$ to $\mathrm{C}_{18}$ fatty acids.

${ }^{4}$ Nonfiber carbohydrates; calculated as $100-[\mathrm{NDF}$ (percentage $)+\mathrm{CP}$ (percentage $)+$ fat (percentage $)+$ ash (percentage)]. Ash values were derived from NRC (1989) values.

${ }^{5}$ Calculated from NRC (1989) values for individual feedstuffs.

and stored in $4.3 \times 15.2 \mathrm{~m}$ upright concrete stave silos. The composition of each feed was determined (Table 1 ). The chopped hay was an alfalfa-grass mixture. The diets (Table 2) were designed in a manner similar to yr 1. Diet chemical composition and particle size information on ration ingredients are provided in Tables 3 and 6.
STATISTICAL ANALYSIS

Statistical analysis was by Proc Mixed (Littell et al., 1996). The model statement included year, treatment, and year $\times$ treatment. The random statement included square (year), square by treatment (year), period (year $\times$ square), and cow (year $\times$ square). The Satterthwaite

Table 4. Particle size distribution of forages.

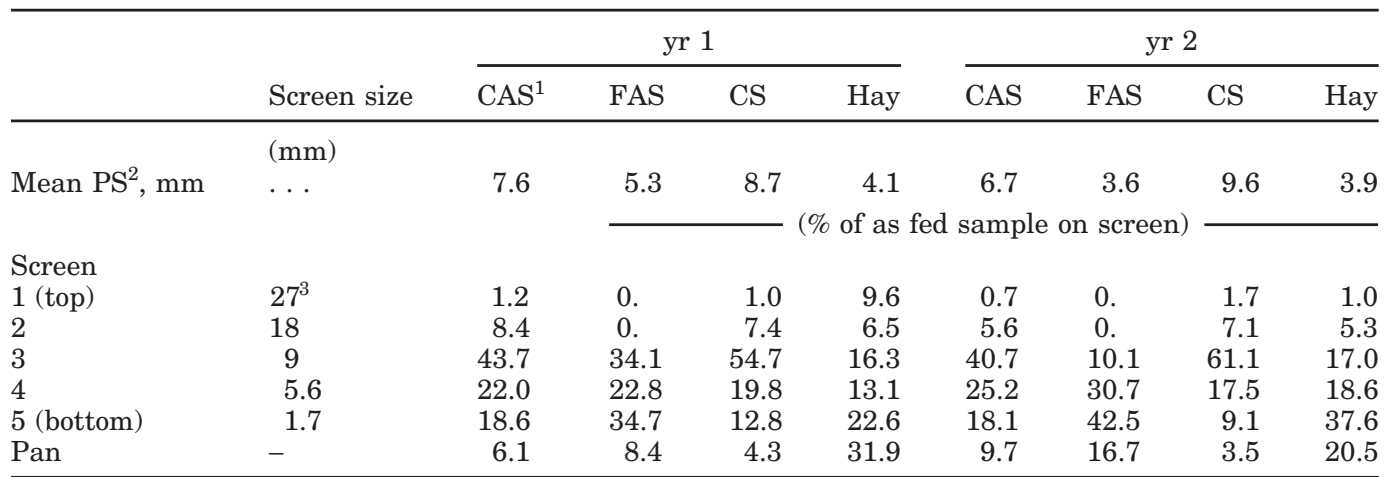

${ }^{1} \mathrm{CAS}=$ Coarser alfalfa silage $\mathrm{CS}=$ corn silage; and FAS $=$ finer alfalfa silage.

${ }^{2}$ Geometric mean particle sizes of forages determined using square hole screens.

${ }^{3}$ Diagonal length of the square hole opening. 
Table 5. Rumination, eating, and total chewing times.

\begin{tabular}{|c|c|c|c|c|c|c|c|c|c|}
\hline \multirow[b]{2}{*}{ Variable } & \multirow[b]{2}{*}{$\mathrm{yr}$} & \multicolumn{5}{|c|}{ Diet } & \multicolumn{3}{|c|}{ Effect } \\
\hline & & BLF & HFCAS & HFMAS & HFFAS & $\mathrm{SE}$ & $\mathrm{A}$ & $\mathrm{L}$ & $\mathrm{Q}$ \\
\hline \multicolumn{10}{|l|}{ Rumination } \\
\hline \multirow[t]{3}{*}{$\operatorname{Min} / \mathrm{d}$} & 1 & 413 & 464 & 397 & 397 & 17.2 & & & \\
\hline & 2 & 418 & 452 & 443 & 420 & 17.2 & & & \\
\hline & Both & 416 & 458 & 420 & 408 & 12.1 & NS & * & NS \\
\hline \multirow[t]{3}{*}{ Min/kg DMI } & 1 & 17.9 & 20.1 & 17.1 & 17.0 & .92 & & & \\
\hline & 2 & 17.5 & 19.2 & 19.3 & 18.4 & .92 & & & \\
\hline & Both & 17.7 & 19.6 & 18.2 & 17.7 & .92 & NS & $*$ & NS \\
\hline \multicolumn{10}{|l|}{ Eating } \\
\hline \multirow[t]{3}{*}{$\mathrm{Min} / \mathrm{d}$} & 1 & 207 & 237 & 237 & 222 & 16.6 & & & \\
\hline & 2 & 234 & 249 & 255 & 233 & 16.6 & & & \\
\hline & Both & 221 & 243 & 246 & 227 & 11.8 & $*$ & NS & NS \\
\hline \multirow[t]{3}{*}{ Min/kg DMI } & 1 & 8.9 & 10.2 & 10.0 & 9.2 & .63 & & & \\
\hline & 2 & 9.8 & 10.6 & 11.1 & 10.0 & .63 & & & \\
\hline & Both & 9.4 & 10.4 & 10.6 & 9.6 & .45 & $*$ & NS & NS \\
\hline \multicolumn{10}{|l|}{ Total chewing } \\
\hline \multirow[t]{3}{*}{$\mathrm{Min} / \mathrm{d}$} & 1 & 619 & 701 & 633 & 617 & 16.1 & & & \\
\hline & 2 & 653 & 701 & 700 & 655 & 16.1 & & & \\
\hline & Both & 636 & 701 & 666 & 636 & 16.1 & $*$ & $*$ & NS \\
\hline \multirow[t]{3}{*}{ Min/kg DMI } & 1 & 26.8 & 30.2 & 27.1 & 26.1 & 1.17 & & & \\
\hline & 2 & 27.4 & 29.8 & 30.5 & 28.4 & 1.17 & & & \\
\hline & Both & 27.1 & 30.0 & 28.8 & 27.3 & .82 & * & * & NS \\
\hline
\end{tabular}

${ }^{1} \mathrm{BLF}=\mathrm{Basal}$, low forage, control diet; HFCAS = high forage, coarser alfalfa silage diet; HFMAS = high forage, medium alfalfa silage diet; and HFFAS = high forage, finer alfalfa silage diet.

${ }^{2} \mathrm{~A}=$ Overall effect of added alfalfa, $\mathrm{L}=$ linear effect of chop length, and $\mathrm{Q}=$ quadratic effect of chop length.

$* P<.05$.

$\mathrm{NS}=P \geq .05$.

degrees of freedom option was specified in the model statement and all other options were by default. Three single degrees of freedom contrasts were made. One contrast compared BLF with the mean of the other diets. Linear and quadratic effects of ALF chop length within the ALF diets were the other contrasts. Significance was declared at $P<0.05$.

\section{RESULTS AND DISCUSSION}

There were no significant year effects or year $\times$ treatment interactions, so treatment significance was determined for data pooled over both years. Square $\times$ treatment interactions were significant for some chewing parameters, so this term was retained in analysis of all

Table 6. Milk yield, milk composition, and DMI.

\begin{tabular}{|c|c|c|c|c|c|c|c|c|}
\hline \multirow[b]{2}{*}{ Variable } & \multicolumn{5}{|c|}{$\operatorname{Diet}^{1}$} & \multicolumn{3}{|c|}{ Effect $^{2}$} \\
\hline & BLF & HFCAS & HFMAS & HFFAS & $\mathrm{SE}$ & $\mathrm{A}$ & $\mathrm{L}$ & $\mathrm{Q}$ \\
\hline Milk, kg/d & 37.3 & 34.6 & 35.6 & 35.6 & 2.0 & $*$ & NS & NS \\
\hline $\begin{array}{l}4.0 \% \mathrm{FCM}, \mathrm{kg} / \mathrm{d} \\
\text { Milk protein }\end{array}$ & 30.7 & 31.7 & 32.4 & 32.6 & 1.7 & $*$ & $\mathrm{NS}$ & NS \\
\hline$\%$ & 3.26 & 3.18 & 3.15 & 3.16 & 0.06 & $*$ & NS & NS \\
\hline $\begin{array}{l}\text { g/d } \\
\text { Milk fat }\end{array}$ & 1204 & 1090 & 1109 & 1113 & 51 & $*$ & $\mathrm{NS}$ & NS \\
\hline$\%$ & 2.87 & 3.44 & 3.43 & 3.46 & 0.12 & $*$ & NS & $\mathrm{NS}$ \\
\hline $\mathrm{g} / \mathrm{d}$ & 1052 & 1188 & 1216 & 1224 & 71 & * & NS & NS \\
\hline DMI, kg/d & 23.6 & 23.6 & 23.3 & 23.7 & 0.6 & NS & NS & NS \\
\hline
\end{tabular}

\footnotetext{
${ }^{1} \mathrm{BLF}=$ Basal, low forage, control diet; HFCAS = high forage, coarser alfalfa silage diet; HFMAS = high forage, medium alfalfa silage diet; and HFFAS = high forage, finer alfalfa silage diet.

${ }^{2} \mathrm{~A}=$ Overall effect of added alfalfa, $\mathrm{L}=$ linear effect of chop length and $\mathrm{Q}$ = quadratic effect of chop length.

$* P<.05$.

$\mathrm{NS}=P \geq .05$.
} 
chewing data but was eliminated from models for milk production and DMI. (Tables 5 and 6).

\section{Diets and Dry Matter Intake}

The compositional data for the diets are shown in Table 2. A greater amount of soybean meal was required in the diets in yr 1 due to the lower level of CP in the ALF compared to yr 2. The main differences among the four diets in each study were the ALF particle size distribution (Table 4) and the amount of concentrate. The 2-yr average arithmetic mean particle sizes for the coarser and finer ALF were 7.2 and $4.5 \mathrm{~mm}$, respectively. Both the coarser and finer alfalfa silages had greater mean particle length in yr 1 than the corresponding silage in yr 2, even though harvesting and processing techniques used were identical. Methods of estimating mean forage particle size and distribution characteristics vary (Murphy and Zhu, 1997). The University of Wisconsin oscillating screen-type separator method (ASAE, 1988) used on the forages in this study includes the recommendation that 15 to $20 \%$ of the sample be retained on the top two screens. The coarser ALF had a 2-yr average of $8 \%$ of the sample retained on screens one and two compared with $0 \%$ for the finer ALF. The corn silage mean particle length average was $9.2 \mathrm{~mm}$, and the average accumulation of particles on the top two screens was $8.6 \%$ for the 2 yr. The dry chopped hay mean particle length averaged $4 \mathrm{~mm}$, and the average accumulation of hay particles on the top two screens was $11.2 \%$ of total. Therefore, even the HFCAS is finer than typically recommended. The 2-yr averages for total particles retained on screens three and four were 65.8 and $48.9 \%$ for the coarser and finer ALF, respectively. Total particle accumulations on screen five and the bottom pan for the coarser and finer ALF were 26.3 and $51.2 \%$, respectively. The TMR were not analyzed for particle size characteristics.

The 2-yr average for concentrate level in the diets was 71.3 and $50.7 \%$ of DM for the BLF and the ALF diets, respectively. Total diet NDF levels averaged 20.9 and $27 \%$, respectively for the BLF and ALF diets. Forage provided an average of $63.2 \%$ of the total diet NDF in the BLF and $80 \%$ in the ALF diets. The NRC (2001) recommends a minimum of $25 \%$ total dietary NDF with a minimum of $19 \%$ NDF ( $76 \%$ of total) from forages. The ALF diets met or exceeded these minimums, but the BLF did not.

There were no differences in DMI among the diets. Alfalfa silage particle size had no influence on DMI (Table 5). Soita et al. (2000) also reported no difference in DMI when lactating cows were fed barley silagebased diets with long or short mean silage particle lengths. Colenbrander et al. (1991) and Grant and Col- enbrander (1990b) also failed to observe any significant effects of ALF particle length on intake. Armentano et al. (1988) fed energy-limiting $80 \%$ ALF diets that were identical except that $38 \%$ of the silage in one diet was rechopped after fermentation to reduce particle length from 5.63 to $3.12 \mathrm{~mm}$. The reduction in silage particle length did not result in any changes in feed intake, feed digestibility, or milk production. However, Fischer et al. (1994) reported greater DMI for multiparous cows fed short ALF compared to long.

\section{Chewing Activity}

Statistical analysis of the chewing data showed that linear, but not quadratic, effects existed within the ALF diets. Because the particle size for HFCAS was finer in yr 2 than yr 1, means are reported for chewing data by year (Table 6), but statistical inference was conducted only for the data pooled across years due to the lack of year $\times$ treatment interactions. The ability of roughages to provide physically effective fiber to stimulate chewing and salivation has been well documented (Allen, 1997). Eating and total chewing times were greater for the added ALF diets compared with BLF (Table 6). This effect was clearly due to the coarser alfalfa silage, since diet HFFAS caused no greater chewing than did BLF. Dhiman et al. (1995) also observed an increase in eating and ruminating time per kilogram of DMI when lactating cows were fed an increased level of ALF in the diet.

In studies (Santini et al., 1983) of forage particle length in diets for lactating cows, forages with particle length $<5 \mathrm{~mm}$ have been associated with reduced chewing activity relative to larger particles. In our study, a linear decrease in total chewing activity, mainly due to a linear decrease in rumination time, was observed as the mean ALF particle size was reduced from coarser to finer. This decrease was numerically larger in yr 1 in accordance with a greater difference between forage particle length in the coarser and finer ALF in yr 1 vs. yr 2. Although the interaction of year $\times$ particle size reduction was not significant, there were strong trends in the interaction levels for chewing time/kg DMI $(P=$ $0.10)$ and rumination time/kg DMI $(P=0.11)$. Eating time was greater for ALF compared to BLF both years, an effect which can be attributed to the coarser alfalfa silage. Grant and Colenbrander (1990b) also reported that cows fed finely chopped silage and hay ruminated about $2.5 \mathrm{~h}$ less daily and spent less time chewing than those fed coarsely chopped forage. Colenbrander et al. (1991) also observed reduced total chewing and rumination times for diets in which one half of the ALF had been rechopped to reduce particle size prior to feeding. Despite reductions in chewing activity, milk fat yield 
and concentration were not affected in those studies nor in the current experiment (Table 5).

Colenbrander et al. (1991) reported that cows spent 28.5 and $13.6 \%$ of the day ruminating and eating, respectively. In our study, cows on the ALF diets spent an average of $29.8 \%$ of the day ruminating and $16.6 \%$ of the day eating. The 3 -wk periods used in this trial were relatively short time intervals. The BLF, HFFAS and HFMAS may not provide adequate physically effective fiber to maintain desired rumen health in cows during the early postpartum period or when used in lactating cow diets for longer time periods.

\section{Milk Yield and Composition}

Milk yield was lower for cows on the diets with ALF compared to BLF (Table 5). However, 4\% FCM yields were higher for cows fed additional ALF due to higher milk fat concentrations. The DMI was not different among diets and, therefore, did not influence yields. Though the average energy level (Table 3 ) in BLF was higher $(1.83 \mathrm{Mcal} / \mathrm{kg})$ than the ALF diets $(1.68 \mathrm{Mcal} /$ $\mathrm{kg}$ ), this difference did not appear to influence FCM yield. There were no linear or quadratic effects of ALF particle length on milk yield or FCM yield. Beauchemin et al. (1994) reported that an increase in ALF theoretical chop length from 5-mm to $10-\mathrm{mm}$ in low fiber diets increased FCM yield but in adequate forage fiber diets it decreased FCM yield.

As expected, milk fat concentrations and fat yields were higher for cows on the ALF diets compared to BLF, which was likely the result of higher NDF levels in the ALF diets due to the added forage (Table 5). The relationship between high concentrate, low forage diets and milk fat depression is well documented (Sutton, 1989). The actual mechanisms involved in milk fat depression have not been fully elucidated, but several theories have been proposed. Theories involving shortage of acetate for milk fat synthesis and increased insulin diverting milk fat away from the mammary gland have largely been replaced in favor of the direct effects of fatty acids with trans double bonds on inhibition of mammary gland de novo milk fat synthesis (Davis and Brown, 1970; Kalscheur et al., 1997; Chouinard et al., 1999).

There were no linear or quadratic effects of ALF particle size on milk fat concentration or fat yield. The fine ALF diet resulted in rumination and eating characteristics very similar to the BLF with markedly different milk component production. When combined with similar milk component production across particle size within the ALF diets, this indicates that chemical, rather than physical, composition of the diet was the primary cause of production differences between the
BLF and ALF diets. A caveat to this conclusion is that a certain amount of coarse material was present in even the BLF and HFFAS diets from corn silage and chopped hay.

The level of physically effective fiber in the ALF diets appeared to meet or exceed that necessary for adequate milk fat synthesis. The particle length of ALF likely may be more critical for maintaining acceptable milk fat concentration when higher concentrate diets are used (Beauchemin et al., 1994). The cows used in this study were in mid-lactation. Adequate forage particle length may be more critical for cows in early lactation or in herds where one TMR is fed to all cows.

There were no linear or quadratic effects of ALF particle size on milk protein concentration or protein yield. Milk protein concentration and protein yield were higher for cows on the higher energy BLF compared with the ALF diets (Table 5). Others have reported a similar response (Beauchemin et al., 1994). A relationship between diet energy level and milk protein concentration is well documented (Emery, 1978; Sutton, 1989). Lack of sufficient energy can depress protein percentage from 0.1 to as much as 0.4 percent. The exact mechanism by which increased diet energy level influences milk protein is still unclear but may be related to increased microbial protein synthesis in the rumen as well as increased blood insulin (Mackle et al., 2000).

\section{CONCLUSIONS}

When diets containing less than $50 \%$ of forage $\mathrm{DM}$ as ALF are properly formulated to contain recommended minimum levels of total NDF and NDF from forage, and other forage sources included in the diet provide some coarse fiber, ALF particle length appears to have little effect on DMI, milk yield, or milk composition. However, rumination and total chewing times were increased linearly with increasing ALF particle size.

\section{ACKNOWLEDGMENTS}

This work was supported by the State of Wisconsin Consortium for Extension and Research in Agriculture and Natural Resources.

\section{REFERENCES}

Allen, M. S. 1997. Relationship between fermentation acid production in the rumen and the requirement for physically effective fiber. J. Dairy Sci. 80:1447.

American Society of Agriculture Engineers. 1995. Method of determining and expressing fineness of feed materials by sieving. Page 461 in ASAE S319.2 in ASAE Standards 1995. St. Joseph, Michigan.

American Society of Agriculture Engineers. 1988. Method of determining and expressing particle size of chopped forage materials by screening. Publ. S424, ASAE, St. Joseph, MI. 
Armentano, L. E., S. C. Pastore, and P. C. Hoffman. 1988. Particle size reduction of alfalfa silage did not alter nutritional quality of high forage diets for dairy cattle. J. Dairy Sci. 71:409-413.

Association of Official Analytical Chemists. 1980. Official Methods of Analysis. 13th ed. AOAC, Washington, DC.

Beauchemin, K. A., B. I. Farr, L. M. Rode, and G. B. Schaalje. 1994. Effects of alfalfa silage chop length and supplementary long hay on chewing and milk production of dairy cows. J. Dairy Sci., 77:1326-1339.

Chouinard, P. Y., L. Corneau, D. M. Barbano, L. E. Metzger, and D. E. Bauman. 1999. Conjugated linoleic acids alter milk fat composition and inhibit milk fat secretion in dairy cows. J. Nutr. 129:1579-1584.

Colenbrander, V. F., C. H. Noller, and R. J. Grant. 1991. Effect of fiber content and particle size of alfalfa silage on performance and chewing behavior. J. Dairy Sci. 74:2681-2690.

Davis, D. L., and R. E. Brown. 1970. Low-fat milk syndrome. Pages 545-565 in Digestion and Metabolism in the Ruminant. A. T. Phillipson, ed. Oriel Press, New Castle upon Tyne, England.

Dhiman, T. R., J. Kleinmans, N. J. Tessmann, H. D. Radloff, and L. D. Satter. 1995. Digestion and energy balance in lactating dairy cows fed varying ratios of alfalfa silage and grain. J. Dairy Sci. 78:330-341.

Emery, R. S. 1978. Feeding for increased protein. J. Dairy Sci. $61: 818-825$.

Fischer, J. M., J. G. Buchanan-Smith, C. Campell, D. G. Grieve, and O. B. Allen. 1994. Effects of forage particle size and long hay for cows fed total mixed rations based on alfalfa and corn. J. Dairy Sci. 77:217-229.

Grant, R. J., and V. F. Colenbrander. 1990a. Milk fat depression in dairy cows: Role of particle size of alfalfa hay. J. Dairy Sci. 73:1823-1833.

Grant, R. J., and V. F. Colenbrander. 1990b. Milk fat depression in dairy cows: Role of silage particle size. J. Dairy Sci. 73:1834-1842.

Jaster, E. H., and M. R. Murphy. 1983. Effects of varying particle size of forage on digestion and chewing behavior of dairy heifers. J. Dairy Sci. 66:802-810.

Kalscheur, K. F., B. B. Teter, L. S. Piperova, and R. A. Erdman. 1997. Effect of dietary forage concentration and buffer addition on duodenal flow of trans- $\mathrm{C}_{18: 1}$ fatty acids and milk fat production in dairy cows. J. Dairy Sci. 80:2104-2114.

Littell, R. C., G. A. Milleken, W. W. Stroup, and R. D. Wolfinger. 1996. SAS System for Mixed Models, SAS Inst. Inc., Cary N. C.

Mackle, T. R., D. A. Dwyer, K. L. Ingvartsen, P. Y. Chouinard, D. A Ross, and D. E. Bauman. 2000. Effects of insulin and postruminal supply of protein or use of amino acids by the mammary gland for milk protein synthesis. J. Dairy Sci. 83:93-105.

Martz, F. A., and R. L. Belyea. 1986. Role of particle size and forage quality in digestion and passage by cattle and sheep. J. Dairy Sci. 69:1996-2008.

Murphy, M. R., and J. S. Zhu. 1997. A comparison of methods to analyze particle size as applied to alfalfa haylage, corn silage, and concentrate mix. J. Dairy Sci. 80:2932-2938.

National Research Council. 1989. Nutrient Requirements of Dairy Cattle. 6th rev. ed. Natl. Acad. Sci., Washington, DC.

National Research Council. 2001. Nutrient Requirements of Dairy Cattle. 7th rev. ed. Natl. Acad. Sci., Washington, DC.

Santini, F. J., A. R. Hardie, N. A. Jorgensen, and M. F. Finner. 1983. Proposed use of adjusted intake based on forage particle length for calculation of roughage indexes. J. Dairy Sci. 66:811.

Shaver, R. D., A. J. Nytes, L. D. Satter, and N. A. Jorgensen. 1986. Influence of amount of feed intake and forage physical form on digestion and passage of prebloom alfalfa hay in dairy cows. J. Dairy Sci. 69:1545-1559.

Soita, H. W., D. A. Christensen, and J. J. McKinnon. 2000. Influence of particle size on the effectiveness of the fiber in barley silage. J. Dairy Sci. 83:2295-2300.

Sukhija, P. S., and D. L. Palmqust. 1988. Rapid method for determination of total fatty acid contents and composition of feedstuffs and feces. J. Agric. Food Chem. 36:1202.

Sutton, J. D. 1989. Altering milk composition by feeding. J. Dairy Sci. 72:2801-2814.

Van Soest, P. J., J. B. Robertson, and B. A. Lewis. 1991. Methods for dietary fiber, neutral detergent fiber, and nonstarch polysaccharides in relation to animal nutrition. J. Dairy Sci. 74:3583.

Woodford. S. T., and M. R. Murphy. 1988. Dietary alteration of particle breakdown and passage from the rumen in lactating dairy cattle. J. Dairy Sci. 71:687. 